Research article

\title{
Effects of water re-allocation in the Ebro river basin: A multiregional input- output and geographical analysis
}

\author{
Miguel A. Almazán-Gómez ${ }^{\mathrm{a}, \mathrm{c}, *}$, Rosa Duarte ${ }^{\mathrm{a}, \mathrm{c}}$, Raquel Langarita ${ }^{\mathrm{b}, \mathrm{c}}$, Julio Sánchez-Chóliz ${ }^{\mathrm{a}, \mathrm{c}}$ \\ ${ }^{a}$ Department of Economic Analysis - University of Zaragoza, Zaragoza, Spain \\ ${ }^{\mathrm{b}}$ Department of Economics and Business Studies - University of La Rioja, Logroño, Spain \\ c IA2- AgriFood Institute of Aragon, Calle Miguel Servet, 177, 50013, Zaragoza, Spain
}

\section{A R T I C L E I N F O}

\section{Keywords:}

Multiregional input-output

Water re-allocation

Ebro river basin

Water footprint

Socioeconomic impacts

\begin{abstract}
A B S T R A C T
The quality and availability of water are affected by numerous variables, through which the evaluation of water uses from different perspectives, and policy proposals to save water have now become essential. This paper aims to study water use and the water footprint from a river basin perspective, taking into account regions, sectors, and municipalities, while considering the physical frontier along with the administrative sectors. To this end, we have constructed a multi-regional input-output table for the Ebro river basin, disaggregating the primary sector into 18 different crops and 6 livestock groups. We pay special attention to crop production because it is the most water-consuming industry. The construction of the multi-regional input-output model represents an important contribution to the literature, in itself, since, to the best of our knowledge, it is the first to be built for this large basin. We extend this multi-regional input-output model to assess the water footprint by sectors and regions within the basin. We use these data to propose two scenarios: reallocating final demand to reduce the blue water footprint (scenario 1), and increasing value added (scenario 2). These scenarios outline the opportunity costs of saving water in socioeconomic terms in the basin. In another application, we downscale the multi-regional inputoutput model results at the municipal level and depict them using a geographical information system, identifying the hotspots and the areas that would pay for the socioeconomic opportunity costs of saving water. Our results suggest that saving $1 \mathrm{hm}^{3}$ of blue water could cost around $€ 41,500$ of value added if we consider the entire basin. However, this water re-allocation implies losses and gains at the municipal level: some municipalities would reduce value added by more than $€ 30,000$, while others would gain more than $€ 85,000$ of value added. These tools and results can be useful for policy makers when considering re-allocating water. The contribution and the novelty of this paper is the construction of the multiregional input-output model for the Ebro river basin, and its link with geographical systems analysis at the municipal level.
\end{abstract}

\section{Introduction}

Water is indispensable for life, for the environment, for human beings, and for industry (Sepehri and Sarrafzadeh, 2018). Freshwater quality and availability are affected by several variables, such as increases in upstream use (Alcamo et al., 2007), or global warming and revegetation (Bielsa and Cazcarro, 2014). These factors are leading to a global decrease in freshwater availability (Gerten et al., 2008). Climate change and food safety are important challenges for human and economic development. Thus, the mitigation of the impact of climate change, and the design of patterns for sustainable consumption and production are among the primary societal challenges (United Nations, 2015).

Fresh water is a natural resource whose value depends on place and time (Hanemann, 2006), since water transport or intra-basin water transfers are expensive. So, given the importance of water and the costs of its transportation, this paper aims to study water use and the water footprint (WF) from a river basin perspective, considering both the physical and administrative contexts.

Specifically, we study the water flows in the Ebro river basin (ERB), which is the largest in Spain $\left(85,500 \mathrm{Km}^{2}\right)$, representing $15 \%$ of the Spanish extension, and whose basin hosts $7.3 \%$ of the Spanish population and $8.53 \%$ of Spanish GDP. The Ebro River runs for $910 \mathrm{~km}$ in a south-easterly direction across northeast Spain, to its delta on the Mediterranean coast midway between Barcelona and Valencia. It has the largest discharge of any Spanish river (average $9281 \mathrm{hm}^{3} /$ year), and its drainage basin, at 85,500 square $\mathrm{km}$, is also Spain's largest. The ERB provides water to more than 3 million people, living in over 1700

\footnotetext{
* Corresponding author. Department of Economic Analysis - University of Zaragoza, Zaragoza, Spain.

E-mail address: malmazan@unizar.es (M.A. Almazán-Gómez).
} 
Table 1

Autonomous communities in the Ebro river basin. Source: Ebro River Basin Authority (CHE, 2014)

\begin{tabular}{lllll}
\hline $\begin{array}{l}\text { Autonomous } \\
\text { Community }\end{array}$ & $\begin{array}{l}\text { Total } \\
\text { area } \\
\left(\mathrm{km}^{2}\right)\end{array}$ & $\begin{array}{l}\text { Area within } \\
\text { the basin } \\
\left(\mathrm{km}^{2}\right)\end{array}$ & $\begin{array}{l}\text { Basin within the } \\
\text { autonomous. } \\
\text { Comm. }\end{array}$ & $\begin{array}{l}\text { Part in the } \\
\text { basin }\end{array}$ \\
\hline Aragon & 47,720 & 42,111 & $88.25 \%$ & $49.21 \%$ \\
Catalonia & 32,091 & 15,635 & $48.72 \%$ & $18.27 \%$ \\
Navarre & 10,390 & 9229 & $88.83 \%$ & $10.79 \%$ \\
Castile-Leon & 94,227 & 8148 & $8.65 \%$ & $9.52 \%$ \\
Rioja & 5045 & 5023 & $99.56 \%$ & $5.87 \%$ \\
$\begin{array}{l}\text { Basque country } \\
\text { Castile-la Mancha }\end{array}$ & 7230 & 2678 & $37.04 \%$ & $3.13 \%$ \\
Valencian & 79,462 & 1119 & $1.41 \%$ & $1.31 \%$ \\
$\quad$ Community & 23,254 & 851 & $3.66 \%$ & $0.99 \%$ \\
Cantabria & 5327 & 775 & $14.55 \%$ & $0.91 \%$ \\
\hline
\end{tabular}

towns and villages, and is one of the most representative semi-arid river basins of the Mediterranean (Milano et al., 2013a). Moreover, according to Valencia et al. (2015), a downward trend in water availability is observable in the ERB, as in other Mediterranean basins (Milano et al., 2013b) and other basins around the world (Gerten et al., 2008).

Regarding the agriculture sector, the ERB represents a very important area. In the ERB, most crop areas, $17,690 \mathrm{~km}^{2}$, are rainfed, while $5744 \mathrm{~km}^{2}$ are irrigated land (INE, 2011). The primary sector is the most water-demanding sector, with more than $4500 \mathrm{hm}^{3} /$ year of a total of $5000 \mathrm{hm}^{3} /$ year used (CHE, 2014). The ERB water is regulated via an extensive network of dams (Tena et al., 2017) and canals. They allow for the allocation of the water where orography and weather promote the better development of agrarian activities. Another main feature of this basin is that it contains, in part or in whole, nine autonomous communities of Spain (see Table 1 and Fig. 1).

In order to propose measures to reduce the WF in the basin and to estimate the socioeconomic effects at the municipal level, we combine the input-output framework with Geographical Information Systems (GIS). The use of the input-output methodology is justified by the significant literature in this field. The input-output framework has been largely used to assess environmental impacts: Leontief (1970) added a row and a column to obtain an environmental model. Lenzen (1998) used the IO framework to study the greenhouse gases embodied in goods and services.

Emissions of $\mathrm{CO}_{2}$ have been analysed using this methodology in several works. Munksgaard et al. (2008) used the input-output framework to measure emissions of $\mathrm{CO}_{2}$ at national, city, and household level. Roibás et al. (2018) used the input-output framework to determine the carbon footprint from a consumer-responsibility perspective, in Galicia, a Spanish region. Long et al. (2018) used the world input-output database (WIOD) to compare levels of embodied $\mathrm{CO}_{2}$ in the international trade of China and Japan. Acquaye et al. (2017) used the WIOD database to develop a global multiregional input-output model to analyse certain supply chains and their effects on $\mathrm{CO} 2$, water consumption, and pollution, among other environmental variables.

This framework is also used to analyse the inter-agents water relationship. Duarte et al. (2002) employed the hypothetical extraction method to analyse the behaviour of the productive sectors as direct and indirect water-consumers in the Spanish economy. There are other papers focused on water pollution or the WF. Lenzen (2009) demonstrated that input-output analysis can be useful in analysing virtual water flows, applying the analysis to a case study of the Australian state of Victoria. Wang et al. (2013) evaluated the WF and the virtual water trade for the case of Beijing, China. Cazcarro et al. (2016) used the input-output framework to analyse the foreign tourism WF. White et al. (2015) also studied the Haihe River Basin's WF and water stress, using a hydro-economic multisectorial model.

There are other papers focused on analysing embodied water trade- flows. Antonelli et al. (2012) analysed green and blue virtual water 'flows' for the Mediterranean Region using the input-output framework. Chen et al. (2012) simulated the global network of embodied water flow, using a top-down approach of input-output simulation for the globalized economy in 2004. Cai et al. (2017) developed a multiregional model for China to analyse the grey water virtual flows among 30 Chinese regions.

In this paper, we construct a multi-regional input-output (MRIO) table for the ERB for 2010 to assess the WF. Since the primary sector, and more specifically crop production, is the largest water consumer in the ERB, we disaggregate it into 36 crops (18 irrigated and 18 rainfed), 6 livestock groups, and the rest of the primary sector (forestry, fishing, and auxiliary activities).

MRIO models usually cover direct and indirect impacts at the country or regional level. However, socioeconomic and environmental impacts take place in much more specific areas. For this reason, we develop a strategy to downscale the MRIO model results at the municipal level, using GIS software. We construct a downscaling matrix using data at the municipal level, such as land use, yields, livestock and other industry outputs, water requirements by production, etc.

The novelty of this paper is the construction of the MRIO model for the Ebro river basin and its link with information at the municipal level and GIS. This MRIO model, to the best of our knowledge, is the first developed for this important area in terms of agriculture, which can be identified as NUT-1. ${ }^{1}$. The analysis in this paper shows the utility of these tools for policymakers in determining the effects of policies on certain socioeconomic variables, and the areas where the effects will be most evident. In this sense, apart from the novelty of constructing an MRIO model for the Ebro river basin, this work goes further in the research, linking it with local information. Moreover, its link with GIS allows the display of the affected areas in a map, which opens a way for the interpretation of results and the identification of the affected areas. This becomes especially interesting when designing possible policies at the district level or for collaboration between municipalities.

The rest of the paper is structured as follows: in Section 2 we explain the methodology and we show the data used for the analysis. Section 3 presents the main results, and particularly the results at the municipal level, for two scenarios, which include changes in water withdrawals and value added. Sections 4 and 5 contain the discussion and conclusions.

\section{Materials and methods}

\subsection{MRIO model for the Ebro river basin}

MRIO tables usually describe the sale and purchase relationships between regions, producers, and consumers within an economy. They show the interdependencies among industries, agents, and regions (sellers by rows, buyers by columns), as we will see later. The construction of the MRIO table for the Ebro river basin consists of several steps, which are explained below.

First, from the world input-output database (WIOD) (Timmer et al., 2015) we obtain the global MRIO table for 2010 and we aggregate it to obtain an MRIO table with three regions: Spain, rest of EU, and rest of World. As noted earlier, one feature of the Ebro basin is that it contains, in whole or in part, nine autonomous communities of Spain, which are, by alphabetical order, Aragon, Basque-Country, Cantabria, Castile-La Mancha, Castile-Leon, Catalonia, La Rioja, Navarre, and Valencian Community. This leads us to develop a multiregional analysis, and we approach the ERB as the part within the basin of the five most representative regions. Attending to the smaller sizes of the area inside the basin, we discard Castile-la Mancha, Valencian Community, and

\footnotetext{
${ }^{1}$ The Ebro river basin has more than 3 Million inhabitants and is part of two Spanish NUT-1: ES2 (Northeast) and ES5 (East).
} 


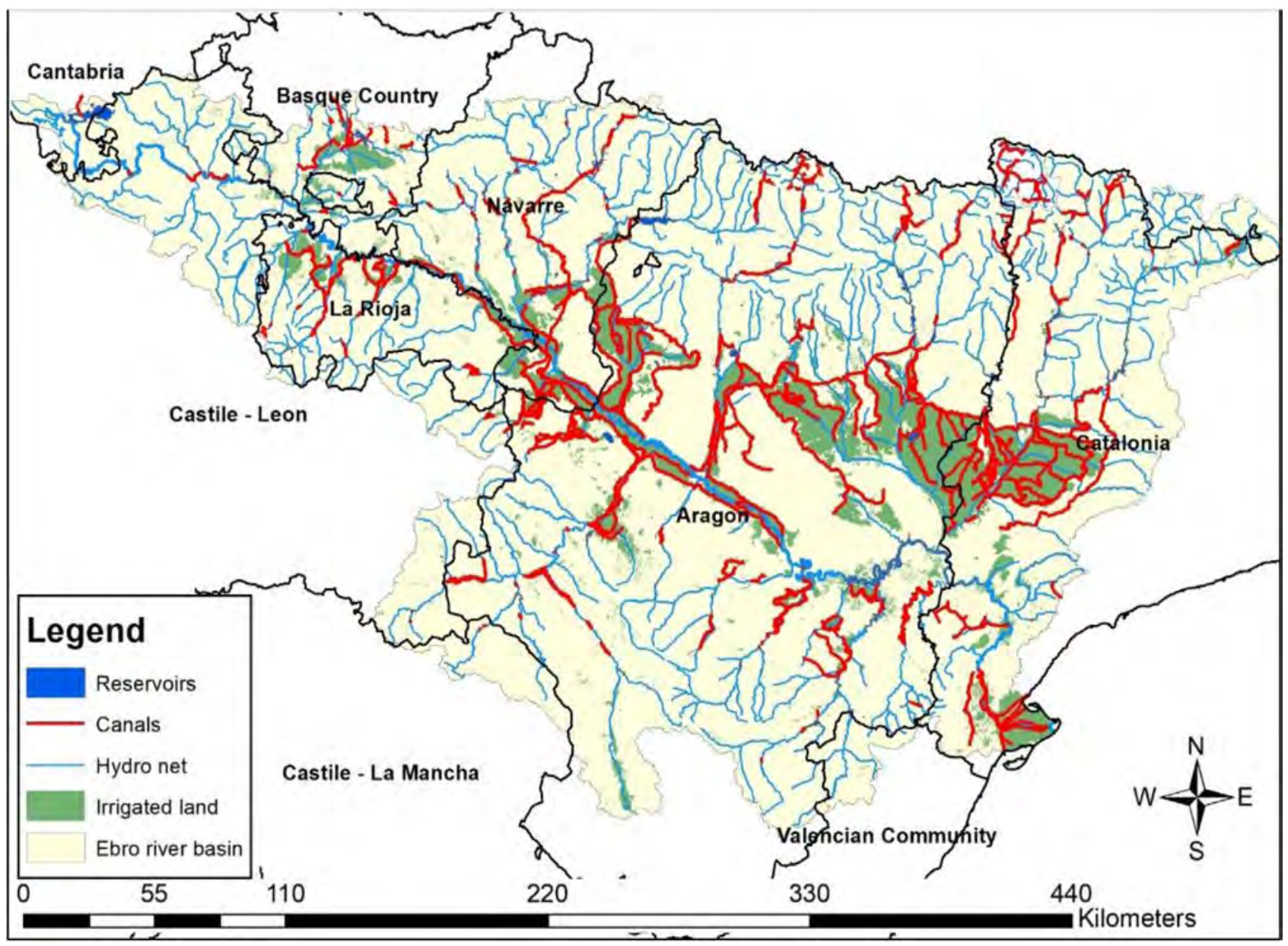

Fig. 1. The Ebro River Basin. Northeast of Spain. Source: Own work. data obtained from MAPAMA (2016).

Cantabria regions. We also discard Castile-Leon, since we consider that the socioeconomic data of that whole autonomous community do not accurately describe the part of the region within the basin (this part of the autonomous community represents less than $7 \%$ of the value added of Castile-Leon and its population). So, for the multiregional analysis, we approach the Ebro river basin as those parts of Aragon, Catalonia, Navarre, La Rioja, and Basque Country that fall inside the basin.

Second, we divide the Spanish table into six smaller tables, according to the regions conforming to the Ebro basin: Aragon, Basque Country, Catalonia, Navarre, La Rioja and rest of Spain. To divide the national table into these six regions, we use the Regional IOTs, the table of Aragon has been obtained from Pérez and Parra (2009), the Basque country table from Eustat (2015), the Catalonia table from IdesCat (2012), the table of Navarre from IEN (2011), and La Rioja table from IELR (2011). We also used data from the Spanish Statistical Office (INE, 2015), the c-intereg database (Llano et al., 2010) to see interregional imports and exports, data from the Spanish Institute for Foreign Trade (ICEX, 2016) to identify international trade at regional level, and data from a previous multiregional model developed for Spain (Cazcarro et al., 2013). In order to facilitate the following disaggregation, explained below, we also disaggregate the primary sector of all Spanish regions (ERB regions and rest of Spain) into 3: agriculture, livestock, and the rest of the primary sector.

Third, to harmonize the table, we apply the improved version of the GRAS algorithm of Lenzen et al. (2007). The GRAS algorithm is an updating method developed by Junius and Oosterhaven (2003), commonly used in the literature to balance tables, which consists of a Generalization of the updating/regionalization RAS method (Stone and Brown, 1962). GRAS is an improvement with respect to the RAS, since it allows the updating of non-squared tables and, in addition, accounts for the existence of negative elements, both in the original table and in the data to be adjusted. ${ }^{2}$

Fourth, since the five regions considered are not completely within the basin, we divide the regional IO tables into two sub-tables, the intrabasin and the trans-basin. To this end, we use the Analysis System of Iberian Balances database (Bureau Van Dijk, 2017). From this database, we obtain, at municipal level, firms-data, such as gross output (approached by operating income), value added, labor force, zip code, etc. Then, we use proportions to estimate the gross output that corresponds to the intra-basin regional IO tables.

To balance these last estimations, we use the GRAS algorithm again. Once we have determined the data that compose the regional IO tables of the ERB, we calculate the rest of Spain IO table by subtraction. Then, to harmonize the MRIO table, we apply the GRAS algorithm once more.

Finally, due to our interest in water, for the ERB regions we have disaggregated the primary sector into 43 activities: 36 different crop productions (18 irrigated and 18 rainfed), 6 livestock groups, and the rest of the primary sector, which covers forestry, fishing, and auxiliary activities. To disaggregate, we take into account land-use data from the

\footnotetext{
${ }^{2}$ The maximization problem of Junius and Oosterhaven (2003) is: Max: $\sum_{j} \sum_{i}\left|x_{i j}\right| \ln \frac{x_{i j}}{a_{i j}}$; and we use the improved version of Lenzen et al. (2007), whose optimization problem is: Max: $\sum_{j} \sum_{i}\left|a_{i j}\right| \frac{x_{i j}}{a_{i j}} \ln \left(\frac{x_{i j} / a_{i j}}{e}\right)$; both subject to. $\sum_{i} x_{i j}=u_{i} ; \sum_{j} x_{i j}=v_{j} ; \sum_{i} u_{i}=\sum_{j} v_{j} ; \forall i$, jwhere $x_{i j}$ is the new component of the table placed in row $i$ and column $j$ and $a_{i j}$ is the old component, also known as "prior", $v_{j}$ is the new sum by rows of column $j$ and $u_{i}$ is the new sum by columns of row $i$.
} 


\begin{tabular}{|c|c|c|c|c|c|}
\hline $\mathrm{x}_{\mathrm{i}, \mathrm{j}}^{1,1}$ & $\ldots$ & $\mathrm{x}_{\mathrm{i}, \mathrm{j}}^{1,8}$ & $\mathrm{y}_{\mathrm{i}, \mathrm{d}}^{1,1}$ & $\ldots$ & $\mathrm{y}_{\mathrm{i}, \mathrm{d}}^{1,1}$ \\
\hline$\vdots$ & $\mathrm{x}_{\mathrm{i}, \mathrm{j}}^{\mathrm{r}, \mathrm{s}}$ & $\vdots$ & $\vdots$ & $\mathrm{y}_{\mathrm{i}, \mathrm{d}}^{\mathrm{r}, \mathrm{d}}$ & $\vdots$ \\
\hline $\mathrm{x}_{\mathrm{i}, \mathrm{j}}^{8,1}$ & $\ldots$ & $\mathrm{x}_{\mathrm{i}, \mathrm{j}}^{8,8}$ & $\mathrm{y}_{\mathrm{i}, \mathrm{d}}^{8,1}$ & $\ldots$ & $\mathrm{y}_{\mathrm{i}, \mathrm{d}}^{8,8}$ \\
\hline $\mathrm{v}_{\mathrm{j}}^{1}$ & $\ldots$ & $\mathrm{v}_{\mathrm{j}}^{8}$ & \multicolumn{2}{|l}{} \\
\cline { 1 - 3 } & &
\end{tabular}

Fig. 2. Structure of the MRIO table of the Ebro river basin - $x_{i, j}^{r, s}$ are the components of the intermediate inputs matrix $\mathrm{X}$ (denoting the intersectoral trade), composed of submatrices $X^{r, s}$. Each $x_{i, j}^{r, s}$ represents the sales from sector i of region $r$ to sector $\mathrm{j}$ of region s. $\mathrm{r}$ and $\mathrm{s}$ indices, from 1 to 8, indicate Aragon, Catalonia, Navarre, Basque country, La Rioja, rest of Spain, rest of European Union, and rest of World respectively. Indices $\mathrm{i}$ and $\mathrm{j}$ represent sectors (see Table SI1 in the Supplementary Information). $y_{i, d}^{r, s}$ represents the components of the final demand matrix $\mathrm{Y}$, also composed of submatrices $Y^{r, s}$. Each $y_{i, d}^{r, s}$ represents the sales from sector $i$ of region $r$ to component $d$ of the final demand of region s. Index d, from 1 to 4, are Households, Government, Gross capital formation, and Changes in inventories and values respectively. $v_{s}^{j}$ represents the value added of sector $\mathrm{j}$ in region $\mathrm{s}$.

last agrarian census (INE, 2011), yield-data from MAGRAMA (2011), crop-prices obtained from the "price received by farmers and ranchers" survey (IAEST, 2013) and "Technical and economic data of agricultural holdings in Aragon" (MAGRAMA, 2013). Then, we use the GRAS algorithm to balance the table and to obtain the final estimation. As a result, the MRIO table of the ERB takes into account 428 productive sectors, as can be seen in Table SI1 of the Supplementary Information: 69 ( 36 crops +6 livestock +1 rest of primary sector +26 non-primary sectors) sectors by 5 regions; 29 sectors ( 1 crop production +1 livestock +1 rest of primary sector +26 non-primary sectors) from rest of Spain; and 27 sectors (primary sector is not disaggregated) by 2 regions (rest of EU and rest of World), and 32 components of final demand: 4 (Households, Government, Gross capital formation, and Changes in inventories and valuables) by 8 regions. Then, the final structure of the MRIO table of the Ebro basin is the following (Fig. 2), with the 6 Spanish regions plus rest of EU, plus rest of World:

Reading the table by columns, we can observe the productive structure of each sector of each region, and the dependencies of other sectors of other regions. Meanwhile, reading it by rows, we can observe the destination of the production. Since the table represents a closed economy (the whole world), sums by columns coincide with sums by rows (see equation (1)).

$\sum_{r} \sum_{i} x_{i, j}^{r, s}+v_{j}^{s}=\sum_{z} \sum_{u} x_{j, u}^{s, z}+\sum_{z} \sum_{d} y_{j, d}^{s, z}=x_{j}^{s} ; \quad \forall i, j, r, s, d, u, z$

where $x_{j}^{s}$ represents the total output of sector $j$ from region $s$. From the MRIO table of the ERB (Fig. 2) we obtain the matrix of technical coefficients, A, which represents direct needs from sector $\mathrm{j}$ per Euro produced by sector $i$, and whose components are the $a_{r, s}^{i, j}$ calculated following equation (2). we can describe the multiregional links in a matrix form (equation (3)).

$a_{i, j}^{r, s}=\frac{X_{i, j}^{r, s}}{x_{j}^{s}}$

$\mathbf{x}=\mathbf{A x}+\mathbf{Y e} \leftrightarrow \mathbf{x}=(\mathbf{I}-\mathbf{A})^{-1} \mathbf{Y e}=\mathbf{L y}$

where $\mathrm{I}$ is the identity matrix $(428 \times 428), \mathrm{Y}$ is the final demand matrix, $\mathbf{e}$ is a $(32 \times 1)$ column vector of ones, $\mathbf{L}=(\mathbf{I}-\mathbf{A})^{-1}$ is the Leontief inverse, which indicates the inputs generated by sector $i$ incorporated directly or indirectly to sector $j$ per euro of final demand of sector $j$, $\mathbf{x}$ is the $(428 \times 1)$ Gross Output vector, $\mathbf{y}=$ Ye is the final demand aggregated vector $\left(y_{i}^{r}=\sum_{s} \sum_{d} Y_{i, d}^{r, s}\right)$, which includes different kinds of final demand: households, investment, government expenditures, and exports.

\subsection{Environmental extension: blue and green water footprint}

The definition of WF is close to the concepts of embodied water and virtual water (Hoekstra and Chapagain, 2008). Embodied water is the water necessary to produce a good or service (direct) and the water needed to produce the goods and services involved in its productive process (indirect) (see Chapagain and Orr, 2009). The term "virtual water" is synonymous with "embodied water", but generally refers to embodied water traded as virtual water flows. This indicator takes into account both direct and indirect water use (Hoekstra et al., 2009).

In these terms, there are three kinds of WF: blue, green, and grey (see Hoekstra et al., 2009; Mekonnen and Hoekstra, 2010). The blue WF refers to the volume of freshwater consumed and/or evaporated in the production process (supply chain) of a good or service, when water comes from a freshwater body (surface or groundwater). The green WF refers to the rainwater stored in the soil as soil moisture evapotranspirated (consumed) by plants when they are part of a productive process. The grey WF refers to pollution (not to consumption), and is defined as the amount of freshwater required to assimilate the load of pollutants. Blue and green water are directly associated with water consumption and water availability (Veettil and Mishra, 2018), so, we will focus on these two.

The direct water used by a sector refers to the direct water consumption of the sector and it is only a part of the WF, or the embodied water. However, knowing the water needed by sector per euro of total production, we can obtain the virtual water flow matrix using the inputoutput framework (Roibás et al., 2017). The virtual water flow matrix shows by rows the origins of embodied water, and by columns the destination of the water embodied (see Table 3 ). Thus, totals by rows (usually last column) identify the water used from the region and sector identified by each row; and totals per column (usually the last row) identify the WF.

The data for direct water used have been obtained from the world input output database (see Genty et al., 2012). This dataset is provided for 40 regions and 35 industries, for the period 1995-2009. We estimate the 2010 data, following equation (4):

$\frac{d_{j, 2010}^{s}}{x_{j, 2010}^{s}}-\frac{d_{j, 2009}^{s}}{x_{j, 2009}^{s}}=\frac{d_{j, 2009}^{S}}{x_{j, 2009}^{S}}-\frac{d_{j, 2008}^{S}}{x_{j, 2008}^{s}} ; d_{j, 2010}^{s}=x_{j, 2010}^{S}\left(2 \frac{d_{s, 2009}^{s}}{x_{j, 2009}^{s}}-\frac{d_{s, 2008}^{S}}{x_{j, 2008}^{s}}\right)$

where $d_{j, t}^{s}$ represents the direct water used by sector $j$ in region $s$ and year $t$, and $x_{j, t}^{s}$ represents the gross output of sector $j$ in region $s$ and year $t$. To estimate the direct water used by the ERB regions and the rest of Spain, for non-primary sectors, we assume the same direct water used over output ratio $\left(d_{j, 2010}^{s} / x_{j, 2010}^{s}\right)$ for Spain. For primary sectors, we use land use data (INE, 2011), proportions and coefficients from Cazcarro et al. (2014) and Chapagain and Hoekstra (2004), and water-needs data at the county level from Martínez-Cob (2004); thus, we are also able to estimate the water used in each municipality for feeding each crop. Then, for further actions, we calculate both vectors, direct blue water per euro and direct green water per euro, following equation (5). These vectors are called unit requirements.

$w_{\mathrm{j}}^{\mathrm{s}}=\frac{d_{\mathrm{j}, 2010}^{\mathrm{s}}}{\mathrm{X}_{\mathrm{j}, 2010}^{\mathrm{s}}}$

Thus, we are able to extend environmentally the model using these vectors to obtain the virtual water matrix $(\mathrm{V})$ of the ERB (see equation (6)). To this end, we use $\hat{\mathbf{w}}$ and $\hat{\boldsymbol{y}}$ which are the vector of unit requirements of water (blue or green), and the vector of final demand 
$(\mathbf{y}=\mathbf{Y e})$ diagonalized respectively. $\mathbf{V}(428 \times 428)$ is the virtual water matrix which shows the embodied water traded between sectors and regions.

$\mathbf{V}=\hat{\mathbf{w}} \mathbf{L} \hat{\mathbf{y}}$

\subsection{Downscaling: from regions to municipalities}

As the effects on water resources are usually located in small and specific areas, and MRIO models usually show environmental impacts at a country or regional level only, we propose to extend the MRIO analysis with GIS layers and municipal information. In this way, we will be able to estimate the water used in specific hotspots, to understand those hotspots and their locations, to propose policies at the municipal level, and so on.

We make use of the Bureau Van Dijk (2017) database, since it contains information at the municipal level, sector by sector, about output and other relevant variables, for all sectors except the primary, to discern the proportion that the output of each sector in each municipality represents over the output of each region and sector. To estimate the percentages of the primary sector, we use own-elaboration data that distinguish between irrigated and rainfed crops, and take into account the area dedicated to each crop at the municipal level, as well as different yields by region. Data on crop production and livestock have been calculated using the 2009 census (INE, 2011), with yields from MAGRAMA (2011), and prices from IAEST (2013).

We have used these proportions to estimate the parts of the regional IO tables that are included in the basin (mentioned in section 2.1) and to develop the matrix M. Matrix M $(1448 \times 428)$ contains, by columns, the percentage that the output of each of the 1448 municipalities represents over the gross output of each sector in its region. Once we have matrix $\mathbf{M}$, following equation (7), we can determine, by sector, the gross output at the municipal level, $X_{m}(1448 \times 428)$ using the output vector of the MRIO model, diagonalized. Moreover, substituting $\hat{\mathbf{x}}$ by $\hat{\mathbf{w}} \hat{\mathbf{x}}$ in equation (7), we can allocate blue or green water used at the municipal level. Also, we develop unit requirements vector of value added, to estimate the municipality distribution of this macro-magnitude. We use this vector in the same way that we use the water-related ones.

$\mathbf{X}_{\mathbf{m}}=\mathbf{M} \hat{\mathbf{x}}=\mathbf{M} \widehat{\mathbf{L y}} ; \mathbf{W}_{\mathbf{m}}=\mathbf{M} \hat{\mathbf{w}} \hat{\mathbf{x}}=\mathbf{M} \hat{\mathbf{w}} \widehat{\mathbf{L y}}$

\section{Results}

\subsection{MRIO table for the ERB and virtual water flows}

As introduced in the Methodology section, input-output tables represent the economic flows among sectors and regions. They show by rows the origin of the products or services, and by column the sectors or the final demand agents that purchase them. As noted earlier, the intersectoral trade shows the structural links and dependencies among sectors and regions. Commonly, the last rows depict taxes, value added (VA), and output (as the sum of the intermediate inputs and value added), by sector or region represented in each column. Table 2 depicts the aggregated MRIO table that shows the economic flows in the regions of the Ebro Valley and the trade among the regions: Aragon (ARA), Catalonia (CAT), Navarre (NAV), Basque country (B_C), La Rioja (RIO), and including for each region the trade flows with rest of Spain (R_SP), rest of European Union (R_EU), and rest of world (R_W).

The output of the ERB in 2010 was $€ 179,337$ million, which represents $8.8 \%$ of Spanish gross output, while the VA of the ERB, $€ 77,711$ million, represents $8.0 \%$ of Spanish VA. The ERB output can be divided into intermediate inputs ( $€ 69,736$ million), $38.9 \%$, final demand ( $€ 68,151$ million), $38 \%$, and exports ( $€ 41,450$ million), $9.6 \%$ to rest of Spain, $10.2 \%$ to rest of European Union, and 3.4\% to rest of 
Table 3

Blue plus green virtual water flows by regions $\left(\mathrm{hm}^{3}\right)$.

\begin{tabular}{|c|c|c|c|c|c|c|c|c|c|c|c|}
\hline & ARA & CAT & NAV & B_C & RIO & TOTAL ERB & R_SP & R_EU & R_W & TOTAL EXPORTED & TOTAL $=$ Direct water used \\
\hline ARA & 4594 & 316 & 413 & 66 & 33 & 5422 & 1253 & 209 & 116 & 1578 & 6999 \\
\hline CAT & 632 & 2535 & 69 & 32 & 7 & 3276 & 707 & 165 & 168 & 1040 & 4316 \\
\hline NAV & 99 & 7 & 1085 & 33 & 13 & 1237 & 194 & 53 & 31 & 278 & 1515 \\
\hline B_C & 17 & 2 & 23 & 311 & 11 & 364 & 54 & 15 & 7 & 75 & 440 \\
\hline RIO & 50 & 5 & 58 & 39 & 744 & 896 & 212 & 37 & 22 & 270 & 1167 \\
\hline TOTAL ERB & 5393 & 2865 & 1648 & 481 & 808 & 11,195 & 2419 & 478 & 344 & 3242 & 14,437 \\
\hline R_SP & 935 & 295 & 459 & 296 & 136 & 2122 & 67,155 & 3105 & 1917 & & 74,299 \\
\hline R_EU & 285 & 215 & 129 & 95 & 79 & 803 & 4273 & 489,733 & 38,260 & & 533,069 \\
\hline R_W & 496 & 579 & 277 & 275 & 161 & 1789 & 15,273 & 177,454 & $9,592,907$ & & $9,787,423$ \\
\hline TOTAL IMPORTED & 1716 & 1090 & 865 & 666 & 376 & 4713 & & & & & \\
\hline TOTAL $=W F$ & 7109 & 3955 & 2513 & 1148 & 1184 & 15,908 & 89,120 & 670,770 & $9,633,429$ & & \\
\hline
\end{tabular}

Table 4

Socioeconomic and environmental variables in the ERB regions (million $€$, jobs and $\mathrm{hm}^{3}$ ).

Source: Own Work

\begin{tabular}{|c|c|c|c|c|c|c|}
\hline Region & Sector & Output & VA & Direct blue water used & Direct green water used & Apparent blue water productivity \\
\hline \multirow[t]{7}{*}{ Aragon } & Irrigated crops & 830 & 633 & 1887 & 2208 & 0.34 \\
\hline & Rainfed crops & 615 & 469 & 0 & 2494 & - \\
\hline & Livestock & 1719 & 388 & 131 & 0 & 2.96 \\
\hline & Rest of primary sect. & 115 & 58 & 23 & 74 & 2.52 \\
\hline & Industry & 27,729 & 6997 & 13 & 0 & 538.23 \\
\hline & Construction & 7171 & 2920 & 170 & 0 & 17.18 \\
\hline & Services & 31,641 & 19,473 & 0 & 0 & - \\
\hline \multirow[t]{7}{*}{ Catalonia } & Irrigated crops & 839 & 605 & 1513 & 1860 & 0.40 \\
\hline & Rainfed crops & 233 & 168 & 0 & 651 & - \\
\hline & Livestock & 1559 & 332 & 119 & 0 & 2.79 \\
\hline & Rest of primary sect. & 74 & 35 & 15 & 48 & 2.33 \\
\hline & Industry & 11,642 & 2753 & 8 & 0 & 344.13 \\
\hline & Construction & 4359 & 1619 & 103 & 0 & 15.72 \\
\hline & Services & 15,125 & 9087 & 0 & 0 & - \\
\hline \multirow[t]{7}{*}{ Navarre } & Irrigated crops & 354 & 255 & 359 & 493 & 0.71 \\
\hline & Rainfed crops & 279 & 201 & 0 & 538 & - \\
\hline & Livestock & 363 & 65 & 28 & 0 & 2.32 \\
\hline & Rest of primary sect. & 26 & 14 & 5 & 17 & 2.80 \\
\hline & Industry & 18,221 & 4643 & 10 & 0 & 464.30 \\
\hline & Construction & 2772 & 1350 & 66 & 0 & 20.45 \\
\hline & Services & 15,460 & 9344 & 0 & 0 & - \\
\hline \multirow[t]{7}{*}{ Basque Country } & Irrigated crops & 41 & 28 & 67 & 79 & 0.42 \\
\hline & Rainfed crops & 99 & 68 & 0 & 188 & - \\
\hline & Livestock & 190 & 57 & 14 & 0 & 4.07 \\
\hline & Rest of primary sect. & 5 & 3 & 1 & 3 & 3.00 \\
\hline & Industry & 11,258 & 3055 & 8 & 0 & 381.88 \\
\hline & Construction & 3278 & 962 & 78 & 0 & 12.33 \\
\hline & Services & 7715 & 4872 & 0 & 0 & - \\
\hline \multirow[t]{7}{*}{ La Rioja } & Irrigated crops & 339 & 211 & 374 & 502 & 0.56 \\
\hline & Rainfed crops & 188 & 117 & 0 & 201 & - \\
\hline & Livestock & 84 & 54 & 6 & 0 & 9.00 \\
\hline & Rest of primary sect. & 33 & 16 & 7 & 21 & 2.29 \\
\hline & Industry & 6167 & 1997 & 7 & 0 & 285.29 \\
\hline & Construction & 2071 & 692 & 49 & 0 & 14.12 \\
\hline & Services & 6745 & 4172 & 0 & 0 & - \\
\hline
\end{tabular}

World. The ERB imports goods and services amounting to €44,201 million: $49.4 \%$ from rest of Spain, $35.2 \%$ from rest of European Union, and $15.4 \%$ from rest of World. So, The ERB is a net importer region. The largest producer in the ERB is Aragon ( $€ 69,820$ million), followed by Navarre and Catalonia. Aragon imports from the rest of ERB €4544 million, and its main commercial partner is Catalonia. Navarre and Catalonia have an output of $€ 37,474$ million and $€ 33,830$ million respectively, and their main trading partner is Aragon.

Following equation (6), we obtain the virtual water flows. Table 3 shows the virtual flows of blue plus green water by regions. The virtual water flow matrices show the embodied resource, that is to say, the water in the different regions and sectors, directly and indirectly incorporated in the various steps of the production supply chain. Similarly that input-output tables, the virtual flow matrices show the origin of the resource by rows, and the destination by column. Then, the column sums over the rows show the total water used in production by the corresponding sector or region (the water footprint). Meanwhile, the row sums over the columns can be interpreted as the total water requirements (virtual water) for each sector and region according the final demand.

As can be seen, the table of blue plus green virtual water flow shows that the ERB is a net importer of embodied water. The ERB uses $14,437 \mathrm{hm}^{3}$ from its water, while the ERB embodies $15,908 \mathrm{hm}^{3}$ of virtual water in its production. Thus, the ERB is a net importer of virtual water, which is common in Mediterranean countries due to the usual consumption patterns (Steen-Olsen et al., 2012). Aragon, which uses $48 \%$ of the total ERB water used by production activities, produces goods and services that amount only to $39 \%$ of ERB output. Similarly, Catalonia (part of which is within the ERB) uses $30 \%$ of the ERB water, while the region produces $19 \%$ of the ERB goods \& services (see 
Table 5

Embodiments per euro of final demand in irrigated crop production.

Source: Own Work

\begin{tabular}{|c|c|c|c|c|c|c|c|}
\hline & \multirow[t]{2}{*}{ crop } & \multicolumn{2}{|c|}{ Blue WF $\left(\mathrm{m}^{3} / €\right)$} & \multicolumn{2}{|c|}{ Green WF $\left(\mathrm{m}^{3} / €\right)$} & \multicolumn{2}{|c|}{ Value Added $(€ / €)$} \\
\hline & & In ERB & Abroad & In ERB & Abroad & In ERB & Abroad \\
\hline \multirow[t]{9}{*}{ Aragon } & Wheat & 1.9557 & 0.0036 & 3.2038 & 0.0184 & 0.9860 & 0.0359 \\
\hline & Corn & 2.0764 & 0.0034 & 2.2841 & 0.0174 & 0.9881 & 0.0343 \\
\hline & Barley & 2.0108 & 0.0032 & 3.5168 & 0.0162 & 0.9877 & 0.0345 \\
\hline & Alfalfa & 1.8899 & 0.0070 & 2.1157 & 0.0360 & 0.9471 & 0.0678 \\
\hline & Other fodder & 1.4444 & 0.0052 & 3.2109 & 0.0268 & 0.9613 & 0.0558 \\
\hline & Pome fruits & 2.0107 & 0.0096 & 2.2058 & 0.0494 & 0.9221 & 0.0884 \\
\hline & Stone fruits & 3.7135 & 0.0086 & 4.2648 & 0.0438 & 0.9327 & 0.0796 \\
\hline & Horticulture & 1.2208 & 0.0053 & 1.7080 & 0.0271 & 0.9681 & 0.0507 \\
\hline & Rice & 2.3562 & 0.0053 & 2.1028 & 0.0270 & 0.9684 & 0.0505 \\
\hline \multirow[t]{11}{*}{ Catalonia } & Wheat & 1.5125 & 0.0042 & 2.5569 & 0.0257 & 0.9461 & 0.0556 \\
\hline & Corn & 2.7667 & 0.0026 & 3.2343 & 0.0155 & 0.9565 & 0.0450 \\
\hline & Barley & 1.3153 & 0.0041 & 2.4365 & 0.0247 & 0.9409 & 0.0600 \\
\hline & Other fodder & 0.4969 & 0.0095 & 1.2183 & 0.0582 & 0.9024 & 0.0983 \\
\hline & Citrus frits & 1.5693 & 0.0075 & 2.4461 & 0.0456 & 0.8975 & 0.1007 \\
\hline & Pome fruits & 1.7059 & 0.0107 & 1.9603 & 0.0655 & 0.8899 & 0.1102 \\
\hline & Stone fruits & 3.1482 & 0.0083 & 3.6395 & 0.0506 & 0.8997 & 0.0996 \\
\hline & Horticulture & 2.1577 & 0.0070 & 2.9720 & 0.0429 & 0.9179 & 0.0827 \\
\hline & Olive & 1.5726 & 0.0104 & 2.7501 & 0.0634 & 0.8867 & 0.1131 \\
\hline & Grapevine & 0.5584 & 0.0107 & 0.7402 & 0.0652 & 0.8920 & 0.1082 \\
\hline & Rice & 1.6216 & 0.0070 & 1.3651 & 0.0428 & 0.9179 & 0.0827 \\
\hline \multirow[t]{9}{*}{ Navarre } & Wheat & 0.9676 & 0.0016 & 2.4972 & 0.0078 & 0.9610 & 0.0373 \\
\hline & Corn & 1.4639 & 0.0013 & 1.5306 & 0.0063 & 0.9674 & 0.0320 \\
\hline & Barley & 0.7437 & 0.0017 & 2.7647 & 0.0083 & 0.9568 & 0.0408 \\
\hline & Other fodder & 0.2658 & 0.0048 & 0.6091 & 0.0232 & 0.9198 & 0.0727 \\
\hline & Pome fruits & 1.4602 & 0.0039 & 1.7321 & 0.0186 & 0.9161 & 0.0755 \\
\hline & Stone fruits & 1.7466 & 0.0043 & 2.1309 & 0.0209 & 0.9187 & 0.0735 \\
\hline & Horticulture & 1.3993 & 0.0029 & 1.8264 & 0.0139 & 0.9474 & 0.0491 \\
\hline & Grapevine & 0.5749 & 0.0046 & 0.8816 & 0.0220 & 0.9152 & 0.0763 \\
\hline & Rice & 1.5755 & 0.0029 & 1.3872 & 0.0138 & 0.9481 & 0.0485 \\
\hline \multirow[t]{4}{*}{ Basque Country } & Industrials & 0.1627 & 0.0217 & 0.2452 & 0.1006 & 0.8512 & 0.1379 \\
\hline & Pome fruits & 1.0271 & 0.0232 & 1.2393 & 0.1070 & 0.8430 & 0.1458 \\
\hline & Stone fruits & 3.7018 & 0.0125 & 4.4697 & 0.0576 & 0.8519 & 0.1355 \\
\hline & Rice & 2.2691 & 0.0133 & 2.0028 & 0.0616 & 0.8815 & 0.1088 \\
\hline \multirow{8}{*}{ La Rioja } & Wheat & 0.9435 & 0.0058 & 1.7624 & 0.0294 & 0.8801 & 0.1015 \\
\hline & Barley & 1.1066 & 0.0081 & 1.9108 & 0.0414 & 0.8642 & 0.1167 \\
\hline & Industrials & 0.2045 & 0.0174 & 0.2615 & 0.0872 & 0.8422 & 0.1393 \\
\hline & Pome fruits & 1.0176 & 0.0186 & 1.1750 & 0.0938 & 0.8017 & 0.1769 \\
\hline & Stone fruits & 1.8355 & 0.0170 & 2.2843 & 0.0857 & 0.8111 & 0.1678 \\
\hline & Horticulture & 1.4359 & 0.0159 & 1.9403 & 0.0800 & 0.8302 & 0.1499 \\
\hline & Olive & 0.7262 & 0.0172 & 1.4836 & 0.0870 & 0.8111 & 0.1678 \\
\hline & Grapevine & 0.3286 & 0.0168 & 0.5732 & 0.0845 & 0.8166 & 0.1624 \\
\hline
\end{tabular}

Table 6

Irrigated crops final demand reallocation results.

Source: Own Work

\begin{tabular}{|c|c|c|c|c|c|c|}
\hline \multirow[t]{2}{*}{ Scenario } & \multicolumn{2}{|l|}{ Blue WF (m3) } & \multicolumn{2}{|c|}{ Green WF (m3) } & \multicolumn{2}{|c|}{ Value Added $(€)$} \\
\hline & In ERB & Abroad & In ERB & Abroad & In ERB & Abroad \\
\hline Scenario 1 & $-1,057,266$ & 2297 & $-1,323,459$ & 8249 & $-43,724$ & 26,364 \\
\hline Scenario 2 & 596,768 & -6129 & 852,749 & $-31,245$ & 96,990 & $-67,740$ \\
\hline
\end{tabular}

Table 4). In fact, both regions produce "water-intensive" products, mainly crops and livestock, in a higher proportion than the others. On the other hand, Navarre and Basque Country use $10 \%$ and $3 \%$, respectively, of the ERB water used and they generate $20.9 \%$ and $12.6 \%$ of the ERB gross output, respectively.

Some socioeconomic and water-related variables, separated by sector and region, can be seen in Table 4. In general, the highest output by region are services and industry. The service sector is the largest in Aragon, Catalonia, and La Rioja, where the output of the service sector represents between $43 \%$ and $45 \%$. In Navarre and Basque Country, the sector with the largest output is industry, at close to $50 \%$ in both regions. In these two regions (Navarre and Basque Country), the weight of the primary sector is much lower than in the other three regions, not only in terms of production, but also in value added, which is mostly concentrated in the service sector, which represents more than half of the value added in every single region. The region whose service sector weight is lowest is Basque Country, $54 \%$ of value added; in contrast, the Aragonese service sector represents $63 \%$. The distribution of the main socioeconomic variables differs among regions and sectors. We can identify Basque Country and Navarre as industrial regions, where the primary sector has a significantly lower weight than the other three regions. Within the primary sector, livestock is an activity that distinguishes among regions; it represents $2.5 \%$ and $4.6 \%$ of the output of Aragon and Catalonia, respectively, while in the other regions it represents less than $1 \%$.

Of the water used in production, $4589 \mathrm{hm}^{3}$ of a total $5059 \mathrm{hm}^{3}$ of blue water are consumed by the primary sector, $464 \mathrm{hm}^{3}$ is used by construction sector, and the rest, $46 \mathrm{hm}^{3}$, by industry. Apart from that, 


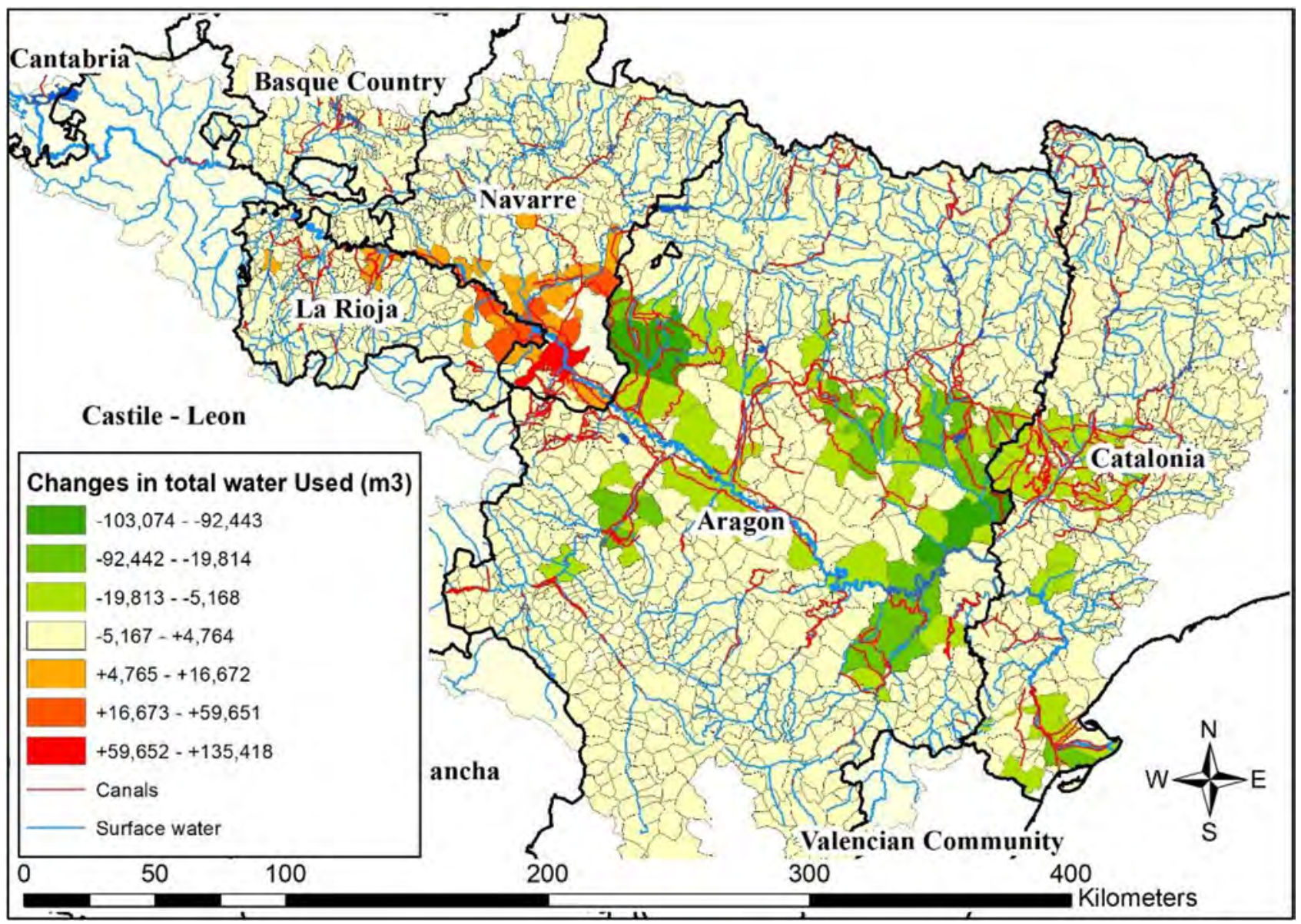

Fig. 3. Changes in blue water used. Total impact on blue water (direct plus indirect) of scenario 1 at the municipal level. Green depicts water-saving areas. Source: own work. Data in cubic meters. (For interpretation of the references to colour in this figure legend, the reader is referred to the Web version of this article.)

the primary sector also uses $9378 \mathrm{hm}^{3}$ of green water. Irrigated crops use $83 \%$ of the blue water used in the ERB, distributed irregularly among regions; Aragon and Catalonia irrigators together use $67 \%$ $\left(3400 \mathrm{hm}^{3}\right)$ of the blue water used in the ERB. Irrigators from La Rioja and Navarre use a similar amount of blue water, which, in sum, represents $14.5 \%$ of the total. Basque Country irrigators use only $67 \mathrm{hm}^{3}$ blue water, which is only $1.3 \%$ of the total. The construction sector uses $9.24 \%$ of the blue water, with no differences among regions in relative terms. Livestock activities consume $2.6 \%$ of blue water in Aragon, and $2.3 \%$ in Catalonia, while the other three regions consume $1 \%$ in total.

We divide value added by direct blue water to obtain the apparent blue water productivity. In the whole ERB, the apparent blue water productivity in irrigated crop production is $0.41 € / \mathrm{m}^{3}$, in livestock, it is $3 € / \mathrm{m}^{3}$, in construction, it is $16 € / \mathrm{m}^{3}$, and in industry $422 € / \mathrm{m}^{3}$. Considering these values of apparent blue water productivity, and taking into account the proportions of blue water used, we focus on crop production to propose alternatives to save water and deal with possible reductions in water availability. The apparent blue water productivity in the ERB for irrigated crops is not the same in the five regions. In Aragon it is $0.33 € / \mathrm{m}^{3}$, in Catalonia $0.40 € / \mathrm{m}^{3}$, in Navarre $0.71 € / \mathrm{m}^{3}$, in Basque Country it is $0.42 € / \mathrm{m}^{3}$, and in La Rioja 0.56 $€ / \mathrm{m}^{3}$. These differences could be caused by the intensity of use, the crop mix (land use) and the productivity of the combination of factors (land, water, capital, and labour) of each crop in each region. The intensity of use can be obtained from Table 4, while the crop mix can be seen in table SI2 of the Supplementary Information. Production in euros (tons multiplied by price) for each crop and each region can be seen in Table SI3 in the Supplementary Information.

We can satisfy the same final demand and reduce the blue WF, substituting the final demand of sectors and regions that provoke a higher WF in the ERB, by demand of the same sectors in the regions that provoke the lowest WF. Table 5 summarizes the data for irrigated crop production embodiments in final demand. The third column identifies the embodied blue water (the blue WF) in one euro of final demand, by sector and region, from the Ebro river basin, and the fourth column identifies the blue WF caused outside the ERB (rest of Spain, rest of European Union, and rest of the World) per euro of final demand. The fifth and sixth columns identify the green WF. Columns 7 and 8 show the embodiments of value added per euro of final demand and where that value added is generated.

As can be seen, the coefficients of the same crop differ by region. These coefficients capture the total effect, that is to say, the direct effect plus the indirect effect. While the direct effect captures the direct use of the resource (blue or green water) or the value added generated, the indirect effect captures the resource embodied in the different stages of the production process; that is, it depends on the productive structure of the region itself and of the regions providing the inputs.

Given the primary character of agricultural goods, the direct effect represents the larger part of the total effect, with the differences in the coefficients depicted in Table 5 being, in great part, associated with the direct effect. The differences in the requirements of water per Euro are mainly motivated by the factors affecting direct water productivities, that is by the climate, by the differences in the productivity of the land, and by the difference in prices.

Using the data in Table 5, we propose two scenarios, in which we reallocate the final demand of crop production, looking to reduce the blue $\mathrm{WF}$, and maximizing the value added. In these scenarios, we use the same strategy: for example, in scenario 1 , we identify for each crop, the 


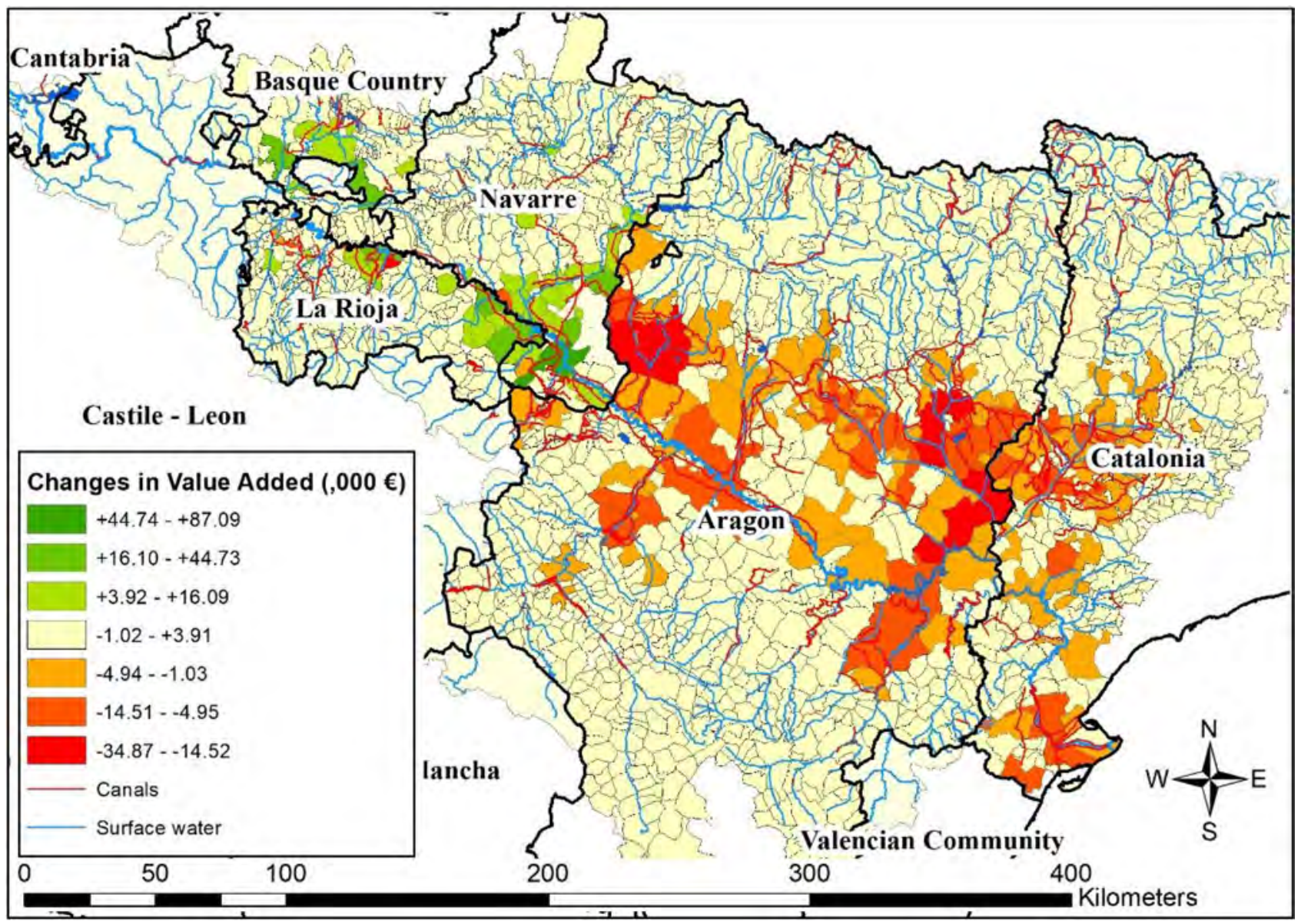

Fig. 4. Changes in value added. Total impact on value added of scenario 1. Green depicts the areas in which the value added would increase. Source: own work. Data in thousand euros. (For interpretation of the references to colour in this figure legend, the reader is referred to the Web version of this article.)

region that, per euro of final demand, provokes the lowest blue WF in the ERB and the region that provokes the highest blue WF in the ERB. Then, we move $€ 100,000$ from the final demand of this crop of the region with the highest WF to this crop in the region that has the lowest $\mathrm{WF}^{3}$. In scenario 2 , we are looking to maximize value added, so we move $€ 100,000$ of final demand from the regions with the lowest value added per unit to the regions with the highest. Results can be seen in Table 6.

As can be seen in Table 6, we can satisfy the same final demand of each crop, saving water (first scenario) or having a higher value added (second scenario). The first scenario shows that we could save $1.06 \mathrm{hm}^{3}$ of blue water and $1.32 \mathrm{hm}^{3}$ of green water; however, value added would decrease by around $€ 44,000$ in the basin. This means that saving a cubic hectometre of blue water would cost around $€ 41,500$ in terms of value added in the whole of the ERB. The second scenario looks to increase the VA by $€ 97,000$, while the blue water and green water also increase, by $0.6 \mathrm{hm}^{3}$ and $0.85 \mathrm{hm}^{3}$ respectively. These scenarios show the opportunity cost, in the cases where we prioritize one objective. Choosing other crops to reallocate their final demand, other trade-offs appear and, since the model we use is linear, other combinations are possible. We use these two scenarios as examples, to show the

\footnotetext{
${ }^{3}$ In scenario 1, we subtract $€ 100,000$ from the final demand of Aragon's wheat (because it has the largest wheat blue WF coefficient) and we add $€ 100,000$ to the final demand of La Rioja's wheat (because it has the largest wheat Blue WF coefficient); we subtract $€ 100,000$ from the final demand of Catalonia's corn and add $€ 100,000$ to the final demand of Navarre's corn; we subtract $€ 100,000$ from the final demand of Aragon's barley and we add $€ 100,000$ to the final demand of Navarre's barley; and so on.
}

capabilities of combining the MRIO table with data at the municipal level and GIS software, and their utility for policymakers. Knowing the trade-offs between environmental and socio-economic variables at global and local level is indispensable for policy makers. Policy makers should also know where and how their decisions will have an effect. For this reason, we develop in 3.2 a strategy to locate the impacts.

\subsection{Downscaling the MRIO results; locating the impacts}

In the previous section, we have seen the trade-off between water and value added in the whole basin. This trade-off exists because of the differences between regions. However, the socio-economic gains or losses occur in more specific areas. Moreover, the ERB has depopulation problems: the ERB represents $15 \%$ of the Spanish surface area, but only has $7.3 \%$ of the Spanish population. Moreover, 400 of the $1400 \mathrm{mu}$ nicipalities considered contain $90 \%$ of the ERB population. For this reason, it is even more important to know the socio-economically affected areas by measures on a more local scale.

MRIO tables usually tell us about environmental impacts at the country or regional level. Thus, to identify the hotspots and quantify the socio-economic impacts and environmental damage in specific areas, we develop a methodology to allocate the standard MRIO model results among municipalities (section 2.3). Since we are considering more than 1400 municipalities, we analyse the results through GIS software (disaggregating results by municipality and also by sector are available on request).

Using equation (7), we have determined the blue and green water used at the municipal level, as well as the value added and its variations through the two scenarios previously depicted. Fig. 3 shows the changes 


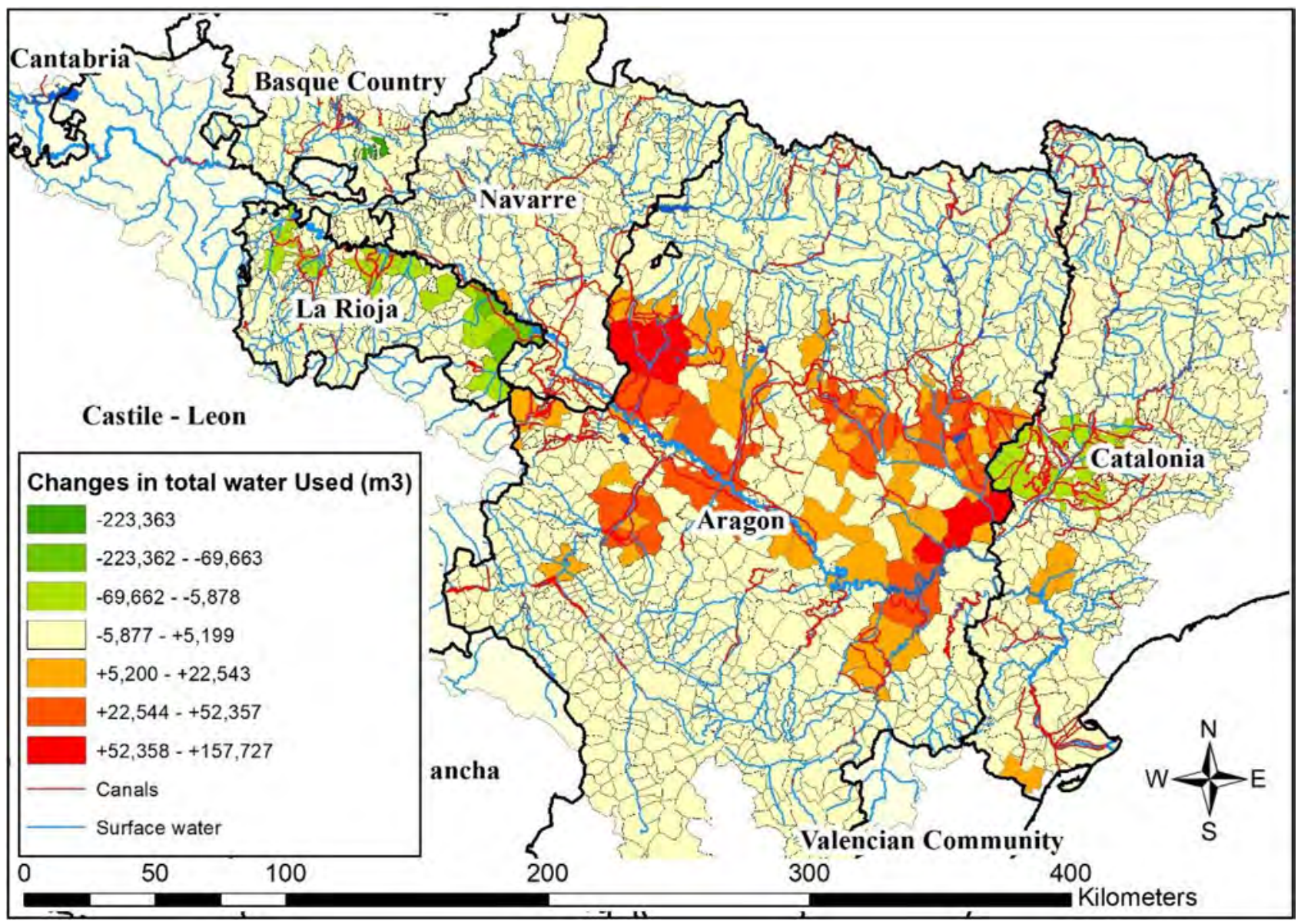

Fig. 5. Changes in blue water used. Total impact on blue water (direct plus indirect) of scenario 2 at the municipal level. Green depicts water-saving areas. Source: own work. Data in cubic meters. (For interpretation of the references to colour in this figure legend, the reader is referred to the Web version of this article.)

in blue water used when we reallocate the final demand of crops among regions to reduce blue water (first scenario). Fig. 4 is related to the first scenario and shows the changes in value added at the municipal level.

As can be seen in Fig. 3, the reallocation of final demand of crops in the first scenario provides a solution that mainly water would be saved in the middle-east and middle-west of Aragon, the west of Catalonia, and in the Ebro Delta. The areas that would increase water withdrawals are, mainly, the south of Navarre and the east of La Rioja. Changes in VA associated with scenario 1 can be seen in Fig. 4, which shows that the areas where the VA would decrease (in red) are mostly the same areas where blue water is being saved. Reductions in water consumption entail reductions in output and in VA, although each municipality is affected in a different way, due to their crop mix and also their water requirements per euro of production.

Figs. 5 and 6 depict the changes in blue water used and in VA at the municipal level, respectively, when we re-allocate final demand of crops among regions to increase the VA in the whole basin (second scenario). As can be seen in Fig. 5, in this scenario, the saving-water areas are mostly in La Rioja, and the intensification of water extractions would be primarily in mid-Aragon. Fig. 6 shows the municipalities where VA increases (green zones) and where it decreases (red zones). As noted earlier, the areas where water use decreases are the areas where VA decreases, and vice-versa. In relative terms, the water withdrawal variations at the municipal level entailed in these scenarios are small. They can be seen in figures SI1 and SI2 in the Supplementary Information. So, these scenarios do not significantly increase the water stress.

\section{Discussion and conclusions}

In the Ebro river basin, water use is already bumping up against its limits. Moreover, different stakeholders are clamouring for greater environmental flows that would imply unaffordable blue water use reductions, see Almazán-Gómez et al. (2018) and Crespo et al. (2018). So, looking for more sustainable patterns, policy makers should propose measures to save water, and local gains and losses should be considered when a policy is being considered.

In this work, we develop a multiregional analysis using the inputoutput framework in the Ebro river basin (ERB). We build a multiregional input-output table, with the primary sector disaggregated. This integrated table and the associated model represent an important result in themselves, since, to the best of our knowledge, they are a first for this large basin. The MRIO table of the ERB considers 8 regions, the 5 regions that make up the basin and 3 regions that represent the rest of the world. The table shows the interdependencies among the different sectors of different regions, and knowledge of these relationships could help to anticipate the impacts of certain policies.

The environmental extension of the model, with water satellite accounts, allows us to depict the virtual water matrices. These matrices tell us about the embodied water flows, which we consider a very useful tool for environmental management. According to our data, the ERB uses $5059 \mathrm{hm}^{3}$ of blue water and $9378 \mathrm{hm}^{3}$ of green water for production. However, the final demand of the ERB products leads to a blue $\mathrm{WF}$ of $4700 \mathrm{hm}^{3}$ and a green WF of $11,208 \mathrm{hm}^{3}$. These data show that, in water-embodied terms, the ERB is exporting blue water and importing green water. Tables 2 and 3 show the input-output table for the $\mathrm{ERB}$, and the blue-plus-green virtual water matrix of the ERB, 


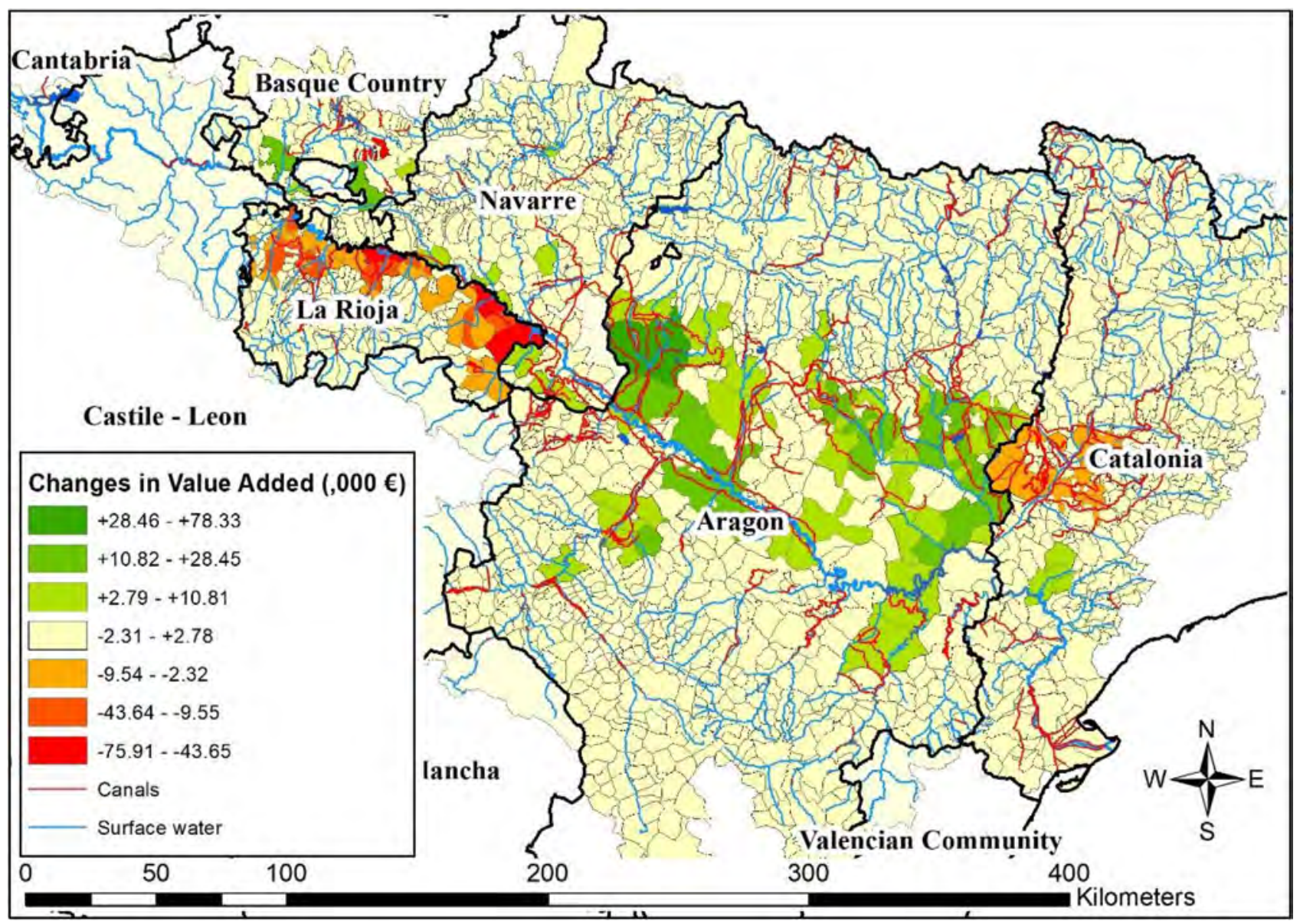

Fig. 6. Changes in value added. Total impact on value added of scenario 2. Green depicts the areas in which the value added would increase. Source: own work. Data in thousand euros. (For interpretation of the references to colour in this figure legend, the reader is referred to the Web version of this article.)

respectively, aggregated by regions. Table 4 shows some socio-economic and water-related data at the sectoral level.

The five ERB regions that we take into account differ - not only by size, but also by their productive structures. Table 4 is useful to characterize the region, and also notes the differences between regions in the ERB. From this table, we can also conclude that crop production is the most water-dependent sector. In addition, Tables SI2 and SI3 in the Supplementary Information show the number of hectares dedicated to each irrigated crop and its production, respectively. The ERB uses around $4200 \mathrm{hm}^{3}$ of blue water in crop production, representing $83 \%$ of the total water withdrawals.

For irrigated crops, we calculate the embodiments per euro of final demand of blue water, green water, and value added, as can be seen in Table 5. From our point of view, these coefficients are significant because they include direct plus indirect effects. We focus only on irrigated crop production, because they have the highest coefficients of blue water, so they have a greater capacity to reduce or to increase the blue WF in the ERB, per euro of final demand. These capacities differ among the regions, so when we consider crops as homogeneous goods, and move final demand of crops with a high blue water coefficient to the same crop of another region that has a lower blue WF per euro of final demand, we satisfy the same final demand, but with a lower WF. As can be seen in Table 5, we have calculated the coefficients of blue water, green water, and value added.

Taking into account the coefficients in Table 5, we propose two scenarios that reallocate final demand of crops among regions. The first scenario aims to save blue water in the ERB, moving $€ 100,000$ of final demand of the crop and region that show the highest blue water coefficient to the final demand of the crop with the lowest blue water coefficient. According to our data, the ERB could save around $1 \mathrm{hm}^{3}$ of blue water and satisfy the same final demand. However, as can be seen in Table 6, this $1 \mathrm{hm}^{3}$ has an opportunity cost in value added terms, suggesting that we should apply other (compensatory) policies to focus on increasing value added when implementing water-saving policies. Note that we focus on the trade-offs between water savings and value added in the Ebro river basin and the spatial distribution of the impacts. For the sake of simplicity and to cover cases with reduced water-uses, in our simulations we chose a small amount of water, $1 \mathrm{hm}^{3}$, since it is enough to appreciate the trade-offs. In the case of a real policy, the quantities would be higher, such as $100 \mathrm{hm}^{3}, 200 \mathrm{hm}^{3}$, and even more.

Knowledge of the trade-off between socio-economic and environmental variables is indispensable for policy makers; moreover, we consider that knowing the specific location of the impacts is also useful; more information leads to better decisions and proposals for compensatory measures. Therefore, we have developed a strategy to downscale the results at the municipal level. The downscaling process uses a matrix of percentages to estimate the allocation of the regional output. When we can allocate the output at the municipal level, we can also allocate other variables using "unit requirement vectors". In section 3.2 we show the estimations of the impacts of the scenarios proposed. Following the first scenario, saving $1 \mathrm{hm}^{3}$ of blue water could cost around $€ 41,500$ of value added if we look at the whole basin. However, there are municipalities that would reduce their value added by more than $€ 30,000$ (e.g., Ejea de los Caballeros, in Aragon, in scenario 1 loses $€ 34,900$ of VA) and others that would gain value added (e.g., Tudela, in Navarre, in scenario 1 gains $€ 87,000$ of VA). As expected, due to direct effects, municipalities that gain the most VA are those that grow the crops with increased final demand. The municipalities that lose the 
most VA are those growing the crops with decreased final demand. However, there are some municipalities that have gains, or suffer losses, that do not grow certain crops because of the indirect effects. We also show the spatial distribution of the environmental and socio-economic effects of the scenarios proposed at the municipal level, using GIS software.

These tools and results can be useful for policy makers when considering re-allocating water. The tools provided represent a contribution in themselves, since they are useful in policy analysis, and the analysis of the scenarios illustrates the utility of the tools provided in this paper, for policymakers to analyse specific areas where the effects will be felt.

We are aware of the limitations of the study, but we trust the usefulness of multiregional and multisectoral models to analyse the socioeconomic and environmental effects of any policy. Moreover, the link with GIS layers allows us to study local effects. One future line of research is the proposal of more realistic scenarios and their analysis using the tools provided in this paper, evaluating not only the effects on socio-economic variables but also the specific places where the effects will be felt.

This work is extensible to other basins and provides a tool for policymakers to estimate not only socio-economic and environmental total impacts, but also where the impacts will be felt. In another future line of research, this MRIO table can be used to calibrate a computable general equilibrium (CGE) model, with which it would be possible to analyse more specific policies of change, as well as local effects. The flexibility of this kind of model also allows us to create links with a hydro-economic model, which is another future line of research.

\section{Acknowledgements}

We would like to express our gratitude for the partial funding received from the Spanish Government under project ECO 2016-74940-P, from the Aragonese Regional Government and FEDER Funds via the S40_17R reference group of the Aragon Government, and grant FPU14/ 01694.

\section{Appendix A. Supplementary data}

Supplementary data to this article can be found online at https:// doi.org/10.1016/j.jenvman.2019.03.042.

\section{References}

Acquaye, A., Feng, K., Oppon, E., Salhi, S., Ibn-Mohammed, T., Genovese, A., Hubacek, K., 2017. Measuring the environmental sustainability performance of global supply chains: a multi-regional input-output analysis for carbon, sulphur oxide and water footprints. J. Environ. Manag. 187, 571-585. https://doi.org/10.1016/j.jenvman. 2016.10.059.

Alcamo, J., Flörke, M., Märker, M., 2007. Future long-term changes in global water resources driven by socio-economic and climatic changes. Hydrol. Sci. J. 52, 247-275. https://doi.org/10.1623/hysj.52.2.247.

Almazán-Gómez, M.Á., Sánchez-Chóliz, J., Sarasa, C., 2018. Environmental flow management: an analysis applied to the Ebro River Basin. J. Clean. Prod. 182, 838-851. https://doi.org/10.1016/j.jclepro.2018.01.207.

Antonelli, M., Roson, R., Sartori, M., 2012. Systemic input-output computation of green and blue virtual water 'flows' with an illustration for the mediterranean region. Water Resour. Manag. 26, 4133-4146. https://doi.org/10.1007/s11269-012-0135-9.

Bielsa, J., Cazcarro, I., 2014. Implementing integrated water resources management in the Ebro river basin: from theory to facts. Sustainability 7, 441-464. https://doi.org/ 10.3390/su7010441.

Bureau Van Dijk, 2017. Iberian Balances Analysis System - Sistema de Análisis de Balances Ibericos (SABI). Online Database [WWW Document]. URL. (Available under license) (accessed 6.1.17). https://sabi.bvdinfo.com/.

Cai, B., Wang, C., Zhang, B., 2017. Worse than imagined: unidentified virtual water flows in China. J. Environ. Manag. 196, 681-691. https://doi.org/10.1016/j.jenvman. 2017.03.062.

Cazcarro, I., Duarte, R., Sánchez-Chóliz, J., 2016. Tracking water footprints at the micro and meso scale: an application to Spanish tourism by regions and municipalities. J. Ind. Ecol. 20, 446-461. https://doi.org/10.1111/jiec.12414.

Cazcarro, I., Duarte, R., Sánchez-Chóliz, J., 2013. Multiregional input-output model for the evaluation of Spanish water flows. Environ. Sci. Technol. 47, 12275-12283. https://doi.org/10.1021/es4019964.

Cazcarro, I., Hoekstra, A.Y., Sánchez-Chóliz, J., 2014. The water footprint of tourism in Spain. Tourism Manag. 40, 90-101. https://doi.org/10.1016/j.tourman.2013.05. 010 .

Chapagain, A.K., Hoekstra, A.Y., 2004. Water Footprints of Nations. The Value of Water Research Report Series BT - Water Footprints of Nations.

Chapagain, A.K., Orr, S., 2009. An improved water footprint methodology linking global consumption to local water resources: a case of Spanish tomatoes. J. Environ. Manag. 90, 1219-1228. https://doi.org/10.1016/j.jenvman.2008.06.006.

CHE (Confederación Hidrográfica del Ebro - Ebro River Basin Authority), 2014. Hydrological management plan. Extracts from the study about environmental flows in the Ebro Delta - Plan Hidrológico de la Cuenca del Ebro. Extracto del estudio sobre el régimen de caudales ecológicos en la Desembocadura del río Ebro (In Spanish) [WWW Document]. URL. 6.28.17. http://www.chebro.es:81/Plan Hidrologico Ebro 2010-2015/.

Chen, Z., Chen, G., Xia, X., Xu, S., 2012. Global network of embodied water flow by systems input-output simulation. Front. Earth Sci. 6, 331-344. https://doi.org/10 1007/s11707-012-0305-3.

Crespo, D., José, A., Kahil, M.T., Esteban, E., 2018. Analysis of sectoral and spatial water allocation in the Ebro River Basin: impacts of shortages and droughts - análisis de la asignación sectorial y espacial del agua en la Cuenca del Ebro : impactos de la escasez y las sequías (In Spanish). Rev. Espanola Estud. Agrosociales Pesq. 250, 127-159.

Duarte, R., Sánchez-Chóliz, J., Bielsa, J., 2002. Water use in the Spanish economy: an input-output approach. Ecol. Econ. 43, 71-85. https://doi.org/10.1016/S09218009(02)00183-0.

Eustat (Instituto Vasco de Estadística - Statistical Office of Basque Country), 2015. InputOutput Framework of Basque Country (In Spanish) [WWW Document]. URL. 6.1.17. http://www.eustat.eus/estadisticas.

Genty, A., Arto, I., Neuwahl, F., 2012. Final Database of Environmental Satellite Accounts. Technical Report on Their Compilation. WIOD Deliverable.

Gerten, D., Rost, S., von Bloh, W., Lucht, W., 2008. Causes of change in 20th century global river discharge. Geophys. Res. Lett. 35, 1-5. https://doi.org/10.1029/ 2008GL035258.

Hanemann, W.M., 2006. The Economic Conception of Water. Water Cris. Myth or Real. pp. 61-91.

Hoekstra, A.Y., Chapagain, A.K., 2008. How much water is used for producing our goods and services? In: Globalization of Water. Blackwell Publishing Ltd, Oxford, UK, pp. 7-17. https://doi.org/10.1002/9780470696224.ch2.

Hoekstra, A.Y., Chapagain, A.K., Aldaya, M.M., Mekonnen, M.M., 2009. Water Footprint Manual State of the Art 2009. Water Footprint Network.

IAEST (Instituto Aragonés de Estadística - Statistical Office of Aragon), 2013. Prices Received by Farmers (In Spanish) [WWW Document]. URL. 1.1.16. http://www. aragon.es/iaest.

ICEX (Instituto Español de Comercio Exterior - Spanish Institute for Foreign Trade), 2016 Spanish Foreign Trade Statistics (In Spanish) [WWW Document]. URL. https:// www.icex.es/.

IdesCat (Instituto de Estadistica de Catalunya - Statistical Office of Catalonia), 2012 Input-output Framework of Catalonia 2011 (In Catalonian) [WWW Document] Marco Input-Output Framew. Catalonia 2011. URL. 6.1.17. http://www.idescat.cat/ dades/mioc/2011/.

IELR (Instituto de Estadística de La Rioja - Statistical Office of La Rioja), 2011. Input Output Table of la Rioja 2008 (In Spanish) [WWW Document]. URL. 6.1.17. http:// www.larioja.org/estadistica/es/publicaciones-informes/catalogo-publicaciones/ marco-input-output-rioja-2008.

IEN (Instituto de Estadística de Navarra - Statistical Office of Navarre), 2011. Inputoutput Framework of Navarre 2010 (In Spanish) [WWW Document]. URL. 6.1.17. https://administracionelectronica.navarra.es/.

INE (Instituto Nacional de Estadística - Spanish National Statistics Institute), 2015. InputOutput framework of Spain - Marco Input-Output de España. [WWW Document]. URL. 6.1.17. www.ine.es.

INE (Instituto Nacional de Estadística - Spanish National Statistics Institute), 2011. Agrarian Census 2009 (In Spanish) [WWW Document]. URL. http://www.ine.es/ CA/Inicio.do.

Junius, T., Oosterhaven, J., 2003. The solution of updating or regionalizing a matrix with both positive and negative entries. Econ. Syst. Res. 15, 87-96. https://doi.org/10. $1080 / 0953531032000056954$.

Lenzen, M., 2009. Understanding virtual water flows: a multiregion input-output case study of Victoria. Water Resour. Res. 45, 1-11. https://doi.org/10.1029/ 2008WR007649.

Lenzen, M., 1998. Primary energy and greenhouse gases embodied in Australian final consumption: an input-output analysis. Energy Policy 26, 495-506. https://doi.org/ 10.1016/S0301-4215(98)00012-3.

Lenzen, M., Wood, R., Gallego, B., 2007. Some comments on the GRAS method. Econ. Syst. Res. 19, 461-465. https://doi.org/10.1080/09535310701698613.

Leontief, W., 1970. Environmental Repercussions and the Economic Structure : an InputOutput Approach, vol. 52. pp. 262-271.

Llano, C., Esteban, A., Pérez, J., Pulido, A., 2010. Opening the interregional trade “"Black box"': the C-intereg database for the Spanish economy (1995-2005). Int. Reg. Sci. Rev. 33, 302-337. https://doi.org/10.1177/0160017610370701.

Long, R., Li, J., Chen, H., Zhang, L., Li, Q., 2018. Embodied carbon dioxide flow in international trade: a comparative analysis based on China and Japan. J. Environ. Manag. 209, 371-381. https://doi.org/10.1016/j.jenvman.2017.12.067.

MAGRAMA (Ministerio de agricultura alimentación y medioambiente - Ministry of Agriculture Food and Environment), 2013. Technical-economic results of agricultural holdings in Aragón in 2012 - Resultados técnico-económicos de explotaciones agrícolas de Aragón en 2012. (In Spanish). 
MAGRAMA (Ministerio de agricultura alimentación y medioambiente - Ministry of Agriculture Food and Environment), 2011. Statistics Yearbook - Anuario de Estadística. (In Spanish).

MAPAMA, 2016. (Ministerio de Agricultura y Pesca Alimentación Y Medio Ambiente Ministry of Agriculture Fishing Food and Environment). National Spatial Data Infraestructure (In Spanish) [WWW Document]. URL. https://www.miteco.gob.es/ en/cartografia-y-sig/ide/descargas/default.aspx.

Martínez-Cob, A., 2004. Review of the net water needs of the Ebro River Basin crops Revisión de las Necesidades Hídricas Netas de los Cultivos de la Cuenca del Ebro. (In Spanish).

Mekonnen, M.M., Hoekstra, A.Y., 2010. A global and high-resolution assessment of the green, blue and grey water footprint of wheat. Hydrol. Earth Syst. Sci. 14, 1259-1276. https://doi.org/10.5194/hess-14-1259-2010.

Milano, M., Ruelland, D., Dezetter, A., Fabre, J., Ardoin-Bardin, S., Servat, E., 2013a Modeling the current and future capacity of water resources to meet water demands in the Ebro basin. J. Hydrol. 500, 114-126. https://doi.org/10.1016/j.jhydrol.2013. 07.010 .

Milano, M., Ruelland, D., Fernandez, S., Dezetter, A., Fabre, J., Servat, E., Fritsch, J.-M., Ardoin-Bardin, S., Thivet, G., 2013b. Current state of Mediterranean water resources and future trends under climatic and anthropogenic changes. Hydrol. Sci. J. 58, 498-518. https://doi.org/10.1080/02626667.2013.774458.

Munksgaard, J., Wier, M., Lenzen, M., Dey, C.J., 2008. Using input-output analysis to measure the environmental pressure of consumption at different spatial levels. J. Ind. Ecol. 9, 169-185. https://doi.org/10.1162/1088198054084699.

Pérez, L., Parra, F.J., 2009. Productivity structure and updating the input-output framework of Aragon 2005 - Estructura productiva y actualización del Marco Input-Output de Aragón 2005 (In Spanish). Colección premios de investigación. Zaragoza.

Roibás, L., Loiseau, E., Hospido, A., 2018. A simplified approach to determine the carbon footprint of a region: key learning points from a Galician study. J. Environ. Manag. 217, 832-844. https://doi.org/10.1016/j.jenvman.2018.04.039.

Roibás, L., Loiseau, E., Hospido, A., 2017. Determination of the carbon footprint of all Galician production and consumption activities: lessons learnt and guidelines for policymakers. J. Environ. Manag. 198, 289-299. https://doi.org/10.1016/j.jenvman. 2017.04.071.

Sepehri, A., Sarrafzadeh, M., 2018. Effect of nitrifiers community on fouling mitigation and nitrification efficiency in a membrane bioreactor. Chem. Eng. Process. - Process Intensif. 128, 10-18. https://doi.org/10.1016/j.cep.2018.04.006.

Steen-Olsen, K., Weinzettel, J., Cranston, G., Ercin, A.E., Hertwich, E.G., 2012. Carbon, land, and water footprint accounts for the European Union: consumption, production, and displacements through international trade. Environ. Sci. Technol. 46, 10883-10891. https://doi.org/10.1021/es301949t.

Stone, R., Brown, A., 1962. A computable model of economic growth. In: A Programme for Growth. Chapman and Hall, London.

Tena, A., Vericat, D., Gonzalo, L.E., Batalla, R.J., 2017. Spatial and temporal dynamics of macrophyte cover in a large regulated river. J. Environ. Manag. 202, 379-391. https://doi.org/10.1016/j.jenvman.2016.11.034.

Timmer, M.P., Dietzenbacher, E., Los, B., Stehrer, R., de Vries, G.J., 2015. An illustrated user guide to the world input-output database: the case of global automotive production. Rev. Int. Econ. 23, 575-605. https://doi.org/10.1111/roie.12178.

United Nations, 2015. The Millennium Development Goals Report. United Nations 72 978-92-1-101320-7.

Valencia, J., Tarquis, A., Saa, A., Villeta, M., Gascó, J., 2015. Spatial modeling of rainfall patterns over the Ebro river basin using multifractality and non-parametric statistical techniques. Water 7, 6204-6227. https://doi.org/10.3390/w7116204.

Veettil, A.V., Mishra, A.K., 2018. Potential influence of climate and anthropogenic variables on water security using blue and green water scarcity, Falkenmark index, and freshwater provision indicator. J. Environ. Manag. 228, 346-362. https://doi.org/10. 1016/j.jenvman.2018.09.012.

Wang, Z., Huang, K., Yang, S., Yu, Y., 2013. An input-output approach to evaluate the water footprint and virtual water trade of Beijing, China. J. Clean. Prod. 42, 172-179. https://doi.org/10.1016/j.jclepro.2012.11.007.

White, D.J., Feng, K., Sun, L., Hubacek, K., 2015. A hydro-economic MRIO analysis of the Haihe River Basin's water footprint and water stress. Ecol. Model. 318, 157-167. https://doi.org/10.1016/j.ecolmodel.2015.01.017. 